\title{
MORAL VALUE AND CHARACTER-BUILDING EDUCATION IN FOLKLORE: SI
} GALE GALE

\section{Nur Jannah'), Sri Karolina Br Surbakti' ${ }^{2}$, Aryani Monita Tarigan ${ }^{3}$, Achida Niasti Veronica Gulo ${ }^{4}$, Yenita Br sembiring*)}

${ }^{1234)}$ English Language Education, Faculty of Teacher Training and Education, University of Prima Indonesia

\begin{abstract}
In character building education and moral values there are significant things that are written in the meaning of folklore as a characteristic of a culture. The aim of this study is to describe folklore as a way to build character education and increasing moral values into an education.

SIGALE-GALE PEOPLE'S STORIES FROM TAPANULI UTARA as source of data in this research. After analyzing and recording important points in the story through a qualitative descriptive method, several things can be obtained that contain character building education and moral values in the SIGALE-GALE story: individual, social, and religious moral values. Which can be applied in attitudes and behaviors in character building education.

This research uses the technique of content analysis, which is a research analysis that reveals the ideas of the author or creator, both manifestly and latently. There for, it can be concluded that the SIGALE-GALE folklore apart from being an education to build character and moral values can also be a means of getting to know ancestors and their stories for future generations.
\end{abstract}

\section{Keywords: character buiding education, moral value, folklore, SIGALE-GALE.}

\begin{abstract}
ABSTRAK
Dalam Pendidikan pembangunan karakter dan nilai moral merupakan hal penting yang dituliskan dalam pengertian cerita rakyat sebgai ciri khas suatu kebudayaan. Tujuan dalam penelitian ini mendeskripsikan cerita rakyat sebagai sarana Pendidikan pembangunan karakter dan penumbuh nilai moral dalam suatu Pendidikan.

Buku SIGALE-GALE CERITA RAKYAT DARI TAPANULI UTARA sebagai sumber dalam pemerolehan data dalam peneltian ini. Setelah menganalisis dan mencatat poin penting dalam cerita melalui metode deskriptif kualitatif, maka dapat diperoleh beberapa hal yang mengandung Pendidikan pembangunan karakter dan nilai moral dalam cerita SIGALE-GALE tersebut: nilai moral individu, social, dan agama. Yang dapat diaplikasikan dalam sikap dan perilaku dalam Pendidikan pembangun karakter

Penelitian ini ini menggunakan Teknik Analisis Isi (content analysis), yakni analisis penelitian yang mengungkap gagasan penulis atau pencipta baik termanifestasi maupun yang laten. Maka dapat disimpulkan bahwa cerita rakyat SIGALE-GALE selain sebagai Pendidikan pembangun karakter dan nilai moral dapat juga sebagai sarana mengenal para leluhur dan kisahnya kepada generasi yang akan datang.
\end{abstract}




\section{CHAPTER I}

\section{INTRODUCTION}

Folklore is one in of many communication mediums that gives valuable messages to audiences. Folklore has educational messages that saved, and must find it, Educational messages in folklore have the same purpose as the transmitting message similar to complexity, because consultation should not only include literary words in the dialogue, but should also interpret each event.

Character training has to be tough since in kinder garden, Elementary school, junior high school, senior high school, and university (Muslich, 2013:15). Therefore, the internalisation of character education, values must begin at the basic level of conventional education and suffer from repetition in a number of environments such as school, family and social life.

Awang (1985:21) mentions that folklore has functions like entertainment, teaching equipment, to encourage society to articulate polite words to appreciate literature as a foundation for creating a subsequent literature work. On the other hand, the folklore of Sigale-gale contains good values of character education that can be a good model. Moral values can be used as a reference norm for a person or a group of people to determine whether the attitudes and action are good or not (Wibawa (2013:173)).

Similar research has been conducted by Arief Setiawan, Sarwiji Suwandi, St. Y. Slamet. (2017), colleges at University of Sebelas Maret with a thesis title educational values of character in Pacitan folklore. The research that is conducted by them has similarities and differences with the researcher. The similarity that will be researched is the character education of a Folklore. While the difference is in the Folklore itself. The researches were about Pacitan Folklore. The researcher used the research of qualitative descriptive method with source of research data in the form of folklore of Pacitan published by Grasindo 2004 that contains 10 titles of story and the data is collected by reading the plot and the content of the meaning or message of each story and recording. The research aims to describe the value of character education when compiling folklore. Thus, in this research, researchers want to reveal the idea of writer or creator at once manifest and latent. The findings show that Pacitan folklore as a literary work contains the value of character education which comprises: 
religious, honest, hard work, creative, curious, spirit of nationalism, respect for fulfilment, love of peace, environmental care, social care and responsibility.

Other similar research has been conducted by Suprani Suprani, Nana Hendracipta (2017), a thesis title of The Analysis of Moral Message on Banten's Folklore and Its Learning Process of Character Education- Oriented at Grade Six Sd Negeri Balaraja 2. The research that is conducted by Suprani Suprani, Nana Hendracipta also has similarities and differences with the researcher. The similarity that will be researched is the moral message and the character education. While the difference is the area or the place. The research by the researchers was about Banten's Folklore. This search was performed using a qualitative descriptive method.

In the meantime, the data collection technique was tested and non-tested by using observation method. As a result of this research, the researcher described the result of the observation showed that the character-oriented education of the moral message. The toward student's attitudes and behavior. The outcome of the research showed that the analysis of the moral message about Banten's Folklore "Oath Mosque of Inland Terate” reached 6.20 (fairly good), on "Legend OF Pinang Mountain" reached 7.45 (good), and on " The Legend of Kuwung Stone" reached 8.00 (very good) and the stories might be concluded the moral message.

There is also other similar research that has been conducted by Rafy Fitriani, Rivi Antoni, and Pipit Rahayu (2016), researchers at University of Pasir Pengaraian with a thesis title $A n$ Analysis of Moral Values in Novel "Oliver Twist" By Charles Dickens. The research that is conducted by them also has similarities and differences with the researcher. The similarity that will be researched is Moral Value. While the difference is the object. The research by Rafy Fitriani, Rivi Antoni, and Pipit Rahayu was about a novel title Oliver Twist by Charles Dickens. The researchers use descriptive qualitative. So that this research, the researcher described the moral values of Oliver Twist Novel by using sociological theory approach to find out the moral values based on functional, symbol, and the conflict perspective. The researchers also used additional information about research problems. Researchers have found certain moral values such as consistency, sympathy for others, bravery, honesty, cooperation, gratitude and kindness.

The achievement and objective of the establishment of character education are expected to make students not only skilled at teaching, but also skilled at character. It is due to the academic ability and impressive intelligence must be complemented with good manners. As a 
result, education will result in outstanding output with an exceptional character (Youpika, 2016:49).

\subsection{Background of study}

Sigale or Si Gale-Gale is a dance performance during the Batak tribal burial ritual from Samosir Island, Lake Toba, which involves mystically wooden doll that have a hundred-year-old legend background. Until this very moment, Si Gale-Gale has many variants of origin. But the most well-known origin, according to the story, this Sigale-Gale doll that can dance was made by a king who lost his son named Manggale. After the death of his son during the war, the king who loved his son very much called a carver and made a Sigale-Gale doll.

\subsection{Problem (s) of Study}

According to the experience of the researcher during the analysis of the folklore of Sigale-Gale, the problem of this study is:

1. What kind of moral value that are contained in Sigale-gale folklore?

2. What kind of characters that we can imitate and apply in Sigale-gale folklore?

\subsection{Object of Study}

According to the experience of the researcher during the analysis of the folklore of Sigale-Gale, the object of this study is:

1. To find out the kind of moral values that are contained in Sigale-gale Folklore

2. To find out of characters that we can imitate and apply in Sigale-gale Folklore

Due to the many variants of origin, the researcher uses a book title SIGALEGALE: Cerita Rakyat dari Tapanuli Utara by S.R.H. Sitanggang (Jakarta, 2010) published by Language Centre, Ministry of National Education.

\subsection{Scope of Study}

Based on the above explanation, this research focuses on studying the moral value and every part of Sigale-Gale folklore that can be used for the character-building process and expressing the values of education especially in order to form the positive character of the generation. The researcher uses descriptive qualitative, 
where the researcher will try to describe and interpret clearly about the elements in the folklore, situation and condition, symptoms and development to see the contribution of the value of the story on moral values and characters building education.

\subsection{Significance of Study}

This research is expected to provide benefits for educational purposes.

\subsubsection{Theoretically}

Another reason for studying folklore and literature is related to the above has sperate aspects: oral literature, like written literature, has an aesthetic dimension. It may be judged by its possessors, from an emic perspective, or from without, by an etic perspective. Some works of oral literature have transcended their milieu; others might if suitably translated and published.

\subsubsection{Practically}

Another reason for the study of folklore is to reveal continuities and relationship between these two forms of art. Perhaps this intuited relationship led many early scholar, to-study oral literature, for they saw it as precursor or ancestor of written literature side by side may reveal on the one hand an author's conscious creativity, his or her change of specific material, thus giving us insight into variation and stability which may be true of all literature, oral or written.

On the other hand, and perhaps more important, the study of two simultaneously may reveal parallel content and themes, styles, form, and structure. The focus in this research is on lore rather than on the folk parse; but trough study of much oral and written lore we may discover general artistic forces of all people.

In order to educate people into cultural values of the society as well as give people motivation and a sense of well-being. 


\section{CHAPTER II}

\section{REVIEW OF LITERATURE}

\subsection{The Nature of Moral Value}

There are kinds of moral values. It includes universal concepts such as bravery, humility, honesty, justice, steadfastness, respectability, accountability, sympathy, cooperation, recognition, reliability, sincerity and others (Hornby, 2010). According to Wibawa (2013:173) moral values can be used as a reference norm to determine whether the attitudes and action are good or not.

As stated by Oxford Advances Learner's Dictionary, moral relates to the standard or principles of good behavior (Hornby, 2010: 959).

\subsection{Character Building Education}

Character education is a program that applies the truth of character to learners. Megangawai (in Arifin and Barnawi: 2012:23) defines character education as an effort to educate children to make wise decisions and apply them in their daily lives. Education in this context is to teach the values, morals and character education that are intended to maintain the value of kindness and to do so in daily life. 


\section{CHAPTER III}

\section{RESEARCH METHOD}

\subsection{Research design}

The research relies on qualitative descriptive research. This research design is part of the qualitative method that enables the researcher to describe a phenomenon by presenting the facts without trying to interpret them. Where the researcher trying to describe and interpret clearly about the elements in the folklore, situation and condition, symptoms and development to see the contribution of the value of the story on moral value and character-building education.

Qualitative research is research that aims to understand the phenomenon of what is experienced by the subject of the study such behavior, perception, motivation, action, and so on, in a holistic manner and by way of description in the form of words and language, in a specific context that is natural and with utilizing a variety of natural methods (Moloeng (2007:6)).

\subsection{Time and Place of Study}

The research will be hold at Tomok Simanindo Kab. Samosir Sumatera Utara on November 2020. The researcher will be conducting the research by analyzing the folklore in order to describe about the moral values and character-building education of the folklore of Sigale-Gale.

\subsection{Instrument of Collecting Data}

The instrument is a necessary tool in getting information. Arikunto (2000: 134) revealed that instrument in collecting data is a tool that is used by researchers to help them in collecting data in order to make it more systematic and easier.

Sugiyono (2008: 222) said that when it comes to qualitative research, the instrument is the researcher himself. Therefore, the researcher should be self-validated in terms of his or her capacity to conduct research.

\subsection{Technique of Collecting Data}

The data are based on the reference form that was used (Arikunto, 1998: 114). Therefore, research is a literary study, they will be considered as the materials of 
research. In gathering the data, the researcher took two types of data: the main data and the supporting data.

This research will use a data collection technique such as the steps to collect the following data:

1. Select folklore in a repetitive and thorough way.

2. Read and learn all relevant materials.

3. Identify for the purpose of finding study data.

4. Categorising the data.

5. Selecting the relevant data

6. Declaring the selected data.

\subsection{Technique of Analyzing Data}

The technique of Analyzing the Data is the process to find and arrange the data. After collecting all of the data, the researchers will start analysing the moral values in folklore "Sigale-gale".

The steps of data analysis of folklore:

a. Collecting relevant references to the analysis of the folklore of Sigale-gale.

b. Extracting the moral values which implied in the folklore of Sigale-gale by relating to the theory of moral values.

c. Analysing the character-building education value of folklore of Sigale-gale.

d. Concluding the data analysis in order to answer the statement of the problem. 


\section{CHAPTER IV}

\section{RESEARCH AND FINDING}

The folklore of the Batak tribe in Samosir regency in this study was obtained from a book by S.R.H Sitanggang entitled Sigalegale Folk Tales from North Tapanuli. From the results story data analysis based on the book, researcher find moral values and character building contained in the quotation of story-quotation data.

\begin{tabular}{|c|c|c|c|c|}
\hline NO. & Quotation of Story & $\begin{array}{l}\text { Moral } \\
\text { Value }\end{array}$ & $\begin{array}{l}\text { Character } \\
\text { Building }\end{array}$ & Page \\
\hline 1 & $\begin{array}{l}\text { "itu kan kata orang! } \\
\text { Perempuan memang lebih } \\
\text { banyak takutnya dari pada } \\
\text { beraninya. Itu pemikiran } \\
\text { kuno! Takhayul, tahu?!” }\end{array}$ & Religious & $\begin{array}{l}\text { Have more faith } \\
\text { in GOD: fear will } \\
\text { always be there, } \\
\text { but we must } \\
\text { always think } \\
\text { positively }\end{array}$ & 2 \\
\hline 2 & $\begin{array}{l}\text { “soal gagak-gagak yang kau } \\
\text { bilang bawa petaka itu.”. } \\
\text { "itu yang aku persoalkan. } \\
\text { Jangan terlalu percaya pada } \\
\text { yang begitu-begitu! Itu } \\
\text { maksudku, Bu!” }\end{array}$ & $\begin{array}{l}\text { Be Positive } \\
\text { (social) }\end{array}$ & $\begin{array}{l}\text { Learn to remind } \\
\text { others } \\
\text { Negative } \\
\text { thoughts will } \\
\text { always exist, but } \\
\text { must be } \\
\text { accompanied by } \\
\text { positive thought } \\
\text { Always thinking } \\
\text { critically will } \\
\text { ultimately have } \\
\text { an impact on } \\
\text { health }\end{array}$ & 2 \\
\hline
\end{tabular}




\begin{tabular}{|c|c|c|c|c|}
\hline 3 & $\begin{array}{l}\text { “maksudku, janganlah } \\
\text { terlalu risau menghadapi } \\
\text { kehidupan ini. Apa pun yang } \\
\text { menjadi guratan nasib kita, } \\
\text { biarlah Mulajadi Na Bolon } \\
\text { yang mengatur. Kita pasrah } \\
\text { saja! Itu maksudku!” }\end{array}$ & Religious & $\begin{array}{l}\text { Surrender more } \\
\text { to GOD } \\
\text { Instill a mindset } \\
\text { : } \\
\text { That one's fate } \\
\text { and destiny have } \\
\text { been determined } \\
\text { by god; we only } \\
\text { need to try our } \\
\text { best. }\end{array}$ & 3 \\
\hline 4 & $\begin{array}{l}\text { "Rahat Raja masih } \\
\text { terbelenggu oleh ikatan } \\
\text { adat-istiadat leluhurnya. } \\
\text { Baginya apa yang } \\
\text { diwariskan oleh para } \\
\text { pendahulunya wajib ditaati } \\
\text { dan dilaksanakan oleh siapa } \\
\text { pun keturunan leluhur si } \\
\text { Raja" }\end{array}$ & $\begin{array}{l}\text { Have respect } \\
\text { (social) }\end{array}$ & $\begin{array}{l}\text { Respect custom } \\
\text { and cultures }\end{array}$ & 4 \\
\hline 5 & $\begin{array}{l}\text { "kalau kita sudah tahu pasti } \\
\text { nama penyakit, barulah kita } \\
\text { tahu obat yang tepat. Dan, } \\
\text {... itu p un kalua ada!" }\end{array}$ & $\begin{array}{l}\text { Be tolerant } \\
\text { (social) }\end{array}$ & $\begin{array}{l}\text { Keep others } \\
\text { people's feeling }\end{array}$ & 7 \\
\hline 6 & 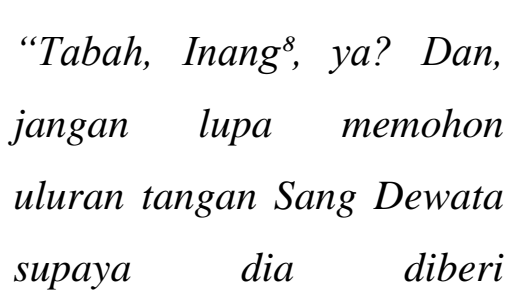 & Religious & Have patient & 7 \\
\hline
\end{tabular}




\begin{tabular}{|c|c|c|c|c|}
\hline & $\begin{array}{l}\text { kesembuhan." } \\
\text { "Inang, Ibu (Mother) }\end{array}$ & & & \\
\hline 7 & $\begin{array}{l}\text { "Tidak ada yang mustahil } \\
\text { dihadapan Dewata" }\end{array}$ & $\begin{array}{l}\text { Have faith and } \\
\text { be positive } \\
\text { (individual) }\end{array}$ & $\begin{array}{l}\text { Have faith in } \\
\text { GOD dan believe } \\
\text { that opportunity } \\
\text { will always be } \\
\text { there }\end{array}$ & 7 \\
\hline 8 & $\begin{array}{l}\text { "itulah rahasia ilahi, } \\
\text { Among! Acapkali hidup kita } \\
\text { ini bagaikan labu. Buahnya } \\
\text { merambat di mana-mana, } \\
\text { tetapi tidak ada yang dekat } \\
\text { pada pangkal pohonnya," } \\
\text { Ompu Sere bertamsil. } \\
\text { "Maksudnya?” } \\
\text { "Artinya, kalau kita tidak } \\
\text { bias mengobati anak sendiri, } \\
\text { mau tidak mau, kita harus } \\
\text { minta tolong kepada orang } \\
\text { lain." }\end{array}$ & $\begin{array}{l}\text { Be dependable } \\
\text { (social) }\end{array}$ & $\begin{array}{l}\text { Emphasize the } \\
\text { mindset: we live } \\
\text { side by side, not } \\
\text { individual }\end{array}$ & 12 \\
\hline 9 & $\begin{array}{l}\text { "Mereka tidak bisa } \\
\text { membayangkan bakal apa } \\
\text { yang menimpa negerinya } \\
\text { seandainya Sang Dewata }\end{array}$ & Be generous & $\begin{array}{l}\text { Be kind to others } \\
\text { and don't be } \\
\text { unrespectful }\end{array}$ & 15 \\
\hline
\end{tabular}




\begin{tabular}{|c|c|c|c|c|}
\hline & $\begin{array}{l}\text { menjemput putra raja itu. } \\
\text { Bagi mereka, Rahat Raja } \\
\text { adalah sosok pengayom dan } \\
\text { Raja bijaksana yang suka } \\
\text { menolong } \\
\text { memperhatikan } \\
\text { kecil." }\end{array}$ & & & \\
\hline 10 & $\begin{array}{l}\text { "Salah satu kebiasaan Rahat } \\
\text { Raja adalah bersilaturahmi } \\
\text { ke rumah para kerabat dan } \\
\text { sanak keluarganya. Setiap } \\
\text { bulan purnama ia bertatap } \\
\text { muka dengan para tetua } \\
\text { adat dan pemuka } \\
\text { masyarakat di balai desa. } \\
\text { Rahat Raja sering mengajak } \\
\text { mereka bertukar pikiran } \\
\text { bagaimana cara } \\
\text { meningkatkan kesejahteraan } \\
\text { warga" }\end{array}$ & $\begin{array}{l}\text { Be tolerant of } \\
\text { differences and } \\
\text { have respect }\end{array}$ & $\begin{array}{l}\text { Discussing and } \\
\text { maintaining in } \\
\text { order to stay in } \\
\text { good touch with } \\
\text { one another }\end{array}$ & 16 \\
\hline 11 & $\begin{array}{l}\text { "Sistem kekerabatan dalihan } \\
\text { na tolu warisan nenek } \\
\text { moyang baginya perlu } \\
\text { dipelihara. Maksudnya, } \\
\text { supaya dalam kehidupan } \\
\text { antar warga tumbuh rasa } \\
\text { saling menghargai. Itulah, } \\
\text { antara lain, yang membuat }\end{array}$ & Be generous & $\begin{array}{l}\text { Treat others as } \\
\text { you want to be } \\
\text { treated }\end{array}$ & 16 \\
\hline
\end{tabular}




\begin{tabular}{|c|c|c|c|c|}
\hline & $\begin{array}{l}\text { rakyat sangat menyayangi } \\
\text { Rahat Raja." }\end{array}$ & & & \\
\hline 12 & $\begin{array}{l}\text { "Semua berharap rezeki hari } \\
\text { ini lebih baik dari hari yang } \\
\text { sudah-sudah. Eh, siapa yang } \\
\text { tahu peruntungan manusia, } \\
\text { kecuali sang Dewata yang } \\
\text { mengendalikan guratan } \\
\text { nasib?!" }\end{array}$ & Have faith & $\begin{array}{l}\text { Have faith in } \\
\text { GOD dan believe } \\
\text { that everything } \\
\text { has its own time } \\
\text { and value }\end{array}$ & 17 \\
\hline 13 & 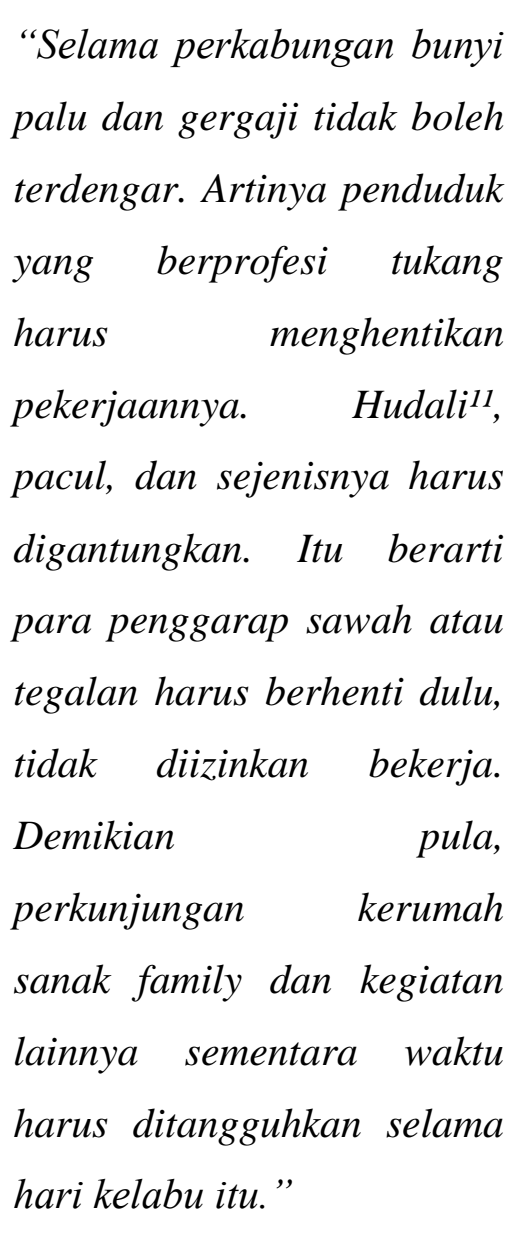 & Be respectful & $\begin{array}{l}\text { Have respect for } \\
\text { yourself and } \\
\text { others }\end{array}$ & 19 \\
\hline 14 & “masa aku hidup tanpa & $\begin{array}{l}\text { Have integrity } \\
\text { (social) }\end{array}$ & $\begin{array}{l}\text { Be honest to } \\
\text { yourself }\end{array}$ & 23 \\
\hline
\end{tabular}




\begin{tabular}{|c|c|c|c|c|}
\hline & $\begin{array}{l}\text { anak? Bagiku anak adalah } \\
\text { segala-galanya. Buat apa } \\
\text { harta, buat apa kekuasaan, } \\
\text { dan bubat apa kewibawaan" }\end{array}$ & & & \\
\hline 15 & $\begin{array}{l}\text { "Permintaan Rahat Raja } \\
\text { sebenarnya sebuah perintah } \\
\text { yang mesti dituruti oleh } \\
\text { rakyatnya" }\end{array}$ & $\begin{array}{l}\text { Be loyal } \\
\text { (individual) }\end{array}$ & Be loyal & 23 \\
\hline 16 & $\begin{array}{l}\text { "Ketika itu para pelayat tak } \\
\text { satu pun yang berani buka } \\
\text { mulut. Bukan karena takut } \\
\text { kepada sang Raja, } \\
\text { melainkan belum paham } \\
\text { benar maksud dan tujuan } \\
\text { pembuatan ptung itu." }\end{array}$ & $\begin{array}{l}\text { Do not judge } \\
\text { (individual) }\end{array}$ & $\begin{array}{l}\text { Do not judge } \\
\text { someone's } \\
\text { decision without } \\
\text { knowing the } \\
\text { intent and } \\
\text { purpose of the } \\
\text { decision itself }\end{array}$ & 24 \\
\hline 17 & $\begin{array}{l}\text { "Terima kasih atas } \\
\text { kepercayaan beliau. Itu saja } \\
\text { yang dapat kusampaikan. } \\
\text { Aku akan berupaya sebisa } \\
\text { mungkin untuk memberikan } \\
\text { yang terbaik buat Rahat } \\
\text { Raja dan kerajaan" }\end{array}$ & $\begin{array}{l}\text { Caring } \\
\text { (social) }\end{array}$ & trustworthiness & 27 \\
\hline 18 & $\begin{array}{l}\text { Rahat Raja tampak sudah } \\
\text { semakin tegar }\end{array}$ & $\begin{array}{l}\text { Acceptance } \\
\text { (individual) }\end{array}$ & Stand tall & 30 \\
\hline
\end{tabular}




\begin{tabular}{|c|c|c|c|c|}
\hline 19 & $\begin{array}{l}\text { "Namun, pikirannya masih } \\
\text { galau karena harapannya } \\
\text { sudah pupus, tidak ada lagi } \\
\text { tunas penyambung anak } \\
\text { cucunya. Putra satu-satunya } \\
\text { sudah dipanggil oleh } \\
\text { Mulajadi Na Bolon, } \\
\text { ssementara putrinya pun } \\
\text { tidakada" }\end{array}$ & $\begin{array}{l}\text { Caring } \\
\text { (social) }\end{array}$ & Affection & 37 \\
\hline 20 & $\begin{array}{l}\text { "Terima kasih, oh Mulajadi } \\
\text { Na Bolon, Engkaulah yang } \\
\text { memberikan kemampuan } \\
\text { kepadaku. Tugasku yang } \\
\text { berat ini sudah selesai. Aku } \\
\text { yakin, Engkaulah yang } \\
\text { memberikan kekuatan dan } \\
\text { kelimpahan rahmat. } \\
\text { Sesungguhnya, ini bukan } \\
\text { karyaku, teteapi atas kuasa } \\
\text { dan berkat-Mu yang begitu } \\
\text { baik." }\end{array}$ & $\begin{array}{l}\text { Trust } \\
\text { (religious) }\end{array}$ & Believes in GOD & 37 \\
\hline 21 & $\begin{array}{l}\text { "Acara perkabungan nanti } \\
\text { harus semarak. Lauk-pauk } \\
\text { yang enak-enak supaya } \\
\text { disajikan dan semuanya } \\
\text { makan } \\
\text { bersama. Harta kekayaanku, } \\
\text { kerbau, lembu, dan unggas- }\end{array}$ & $\begin{array}{l}\text { Be kind and } \\
\text { help each other } \\
\text { (social) }\end{array}$ & Mutual help & 44 \\
\hline
\end{tabular}




\begin{tabular}{|c|c|c|c|c|}
\hline & $\begin{array}{l}\text { unggasku, bahkan emas dan } \\
\text { batu-batu berharga harus } \\
\text { dibagi-bagikan kepada } \\
\text { warga yang tidak berpunya." }\end{array}$ & & & \\
\hline 22 & $\begin{array}{l}\text { "Jika ada di } \\
\text { antara kalian yang sama } \\
\text { guratan nasibnya dengan } \\
\text { aku, } \\
\text { janganlah terlalu risau hati } \\
\text { Peristiwa inilah awal } \\
\text { kebahagiaan kalian." }\end{array}$ & $\begin{array}{l}\text { Be positive } \\
\text { (individual) }\end{array}$ & $\begin{array}{l}\text { Be strong and } \\
\text { keep positive }\end{array}$ & 45 \\
\hline 23 & $\begin{array}{l}\text { "Tentu tidak! Semua itu } \\
\text { bergantung pada kerabat } \\
\text { raja } \\
\text { dan para pengetua adat } \\
\text { dalam acara tonggoraja } \\
\text { nanti," } \\
\text { ujar Ompu Hamonangan. } \\
\text { "Apa yang tidak bisa } \\
\text { dicarikan } \\
\text { solusinya jika dibawa dalam } \\
\text { musyawarah?" }\end{array}$ & $\begin{array}{l}\text { Citizenship } \\
\text { (social) }\end{array}$ & Confabulate & 61 \\
\hline 24 & $\begin{array}{l}\text { "Soal wasiat. Tentang harta } \\
\text { peninggalan almarhum! } \\
\text { Semua harta beliau, rumah }\end{array}$ & $\begin{array}{l}\text { Caring } \\
\text { (individual) }\end{array}$ & Trust & $63-64$ \\
\hline
\end{tabular}




\begin{tabular}{|c|c|c|c|c|}
\hline & $\begin{array}{l}\text { serta sawah-ladang, } \\
\text { termasuk } \\
\text { kerbau dan lembu yang } \\
\text { dilepas liar di lereng } \\
\text { perbukitan sana harus } \\
\text { dibagi-bagikan kepada } \\
\text { wargayang hidupnya ber- } \\
\text { kekurangan," papar Ompu } \\
\text { Hamonangan. }\end{array}$ & & & \\
\hline 25 & $\begin{array}{l}\text { "Hare ... hare, terima kasih } \\
\text { Among! Terima kasih, } \\
\text { Ompung!" }\end{array}$ & $\begin{array}{l}\text { Gratitude } \\
\text { (individual) }\end{array}$ & Happiness & 73 \\
\hline 26 & 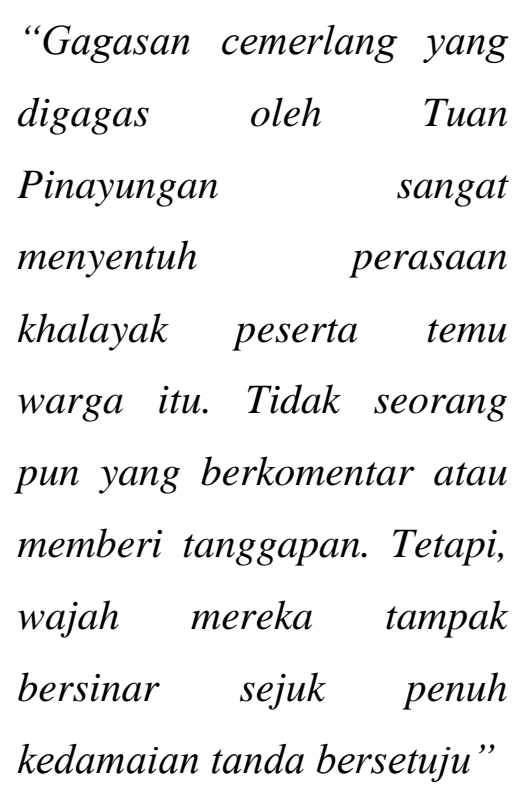 & $\begin{array}{l}\text { Trustworthiness } \\
\text { (individual and } \\
\text { social) }\end{array}$ & Trust worth & 74 \\
\hline 27 & $\begin{array}{l}\text { "Rahat Raja sesungguhnya } \\
\text { adalah manusia biasa sama } \\
\text { seperti warganya. Namun, } \\
\text { perhatian dan ketulusan }\end{array}$ & $\begin{array}{l}\text { Caring } \\
\text { (social) }\end{array}$ & Respect & 74 \\
\hline
\end{tabular}




\begin{tabular}{|c|c|c|c|c|}
\hline & $\begin{array}{l}\text { hatinya untuk menolong } \\
\text { orang berkekurangan tiada } \\
\text { duanya } \\
\text { dengan dibandingkan } \\
\text { sebelumnya" }\end{array}$ & & & \\
\hline 28 & $\begin{array}{l}\text { "Pengabdian } \\
\text { negerinya setara } \\
\text { kasih sayangnya } \\
\text { putranya, yang melebihi } \\
\text { kecintaannya pada dirinya } \\
\text { sendiri" }\end{array}$ & $\begin{array}{l}\text { Caring } \\
\text { (social) }\end{array}$ & $\begin{array}{l}\text { Building } \\
\text { leadership }\end{array}$ & 74 \\
\hline 29 & $\begin{array}{l}\text { "Hatinya adalah sebuah } \\
\text { berlian yang tak lekang } \\
\text { dimakan waktu" }\end{array}$ & $\begin{array}{l}\text { Caring } \\
\text { (social) }\end{array}$ & $\begin{array}{l}\text { Kindness and } \\
\text { pureness }\end{array}$ & 74 \\
\hline 30 & $\begin{array}{l}\text { "ltulah lambang } \\
\text { persahabatan, suatu } \\
\text { perikatan budi yang } \\
\text { terindah, dan lambang kasih } \\
\text { sayang yang tutus dari } \\
\text { seorang ayah kepada } \\
\text { anaknya. Sejatinya, nilai- } \\
\text { nilai kehidupan yang dirajut } \\
\text { oleh Rahat Raja bagai batu } \\
\text { mulia bagi banyak orang. } \\
\text { Namun, bak pepatah: tiada } \\
\text { sungai yang tak beriak." }\end{array}$ & $\begin{array}{l}\text { Caring and } \\
\text { respect } \\
\text { (individual) }\end{array}$ & $\begin{array}{l}\text { Be a father to } \\
\text { your children and } \\
\text { be a leader to } \\
\text { your people }\end{array}$ & 75 \\
\hline
\end{tabular}


From the presentation of research results mentioned, there are three moral values contained in the folklore of Sigalegale, namely individual moral values, social moral values, and religious moral values. The three moral values of character building based on attitudes, behavior and word or verbally as well nonverbal either directly or indirectly straight from the story's characters depicted through story quotes. The following will discuss the three moral values and representation of moral values that are in sigalegale folklore.

\subsection{Individual Moral Values}

Behavior of human relations with himself classified at all form of moral values related to individual as a person who shows will the individual's existence with various attitudes attached to him. Man's problem with himself according to Nurgiyantoro (2012: 324) can various types and levels Intensity. Representation of immoral values individuals in this study consisted of strong attitude, happy, obey and trustworthy.

\section{1) Strong}

A strong person is a person who has a lot of strength. The strength of a person has moral value when that power is used for good things.

\section{2) Happy}

Happiness is a feeling that is felt in the form of feeling happy, at ease, and having peace (Rusydi, 2007).

\section{3) Obey}

Obeying is an attitude that obeys all rules or orders, obeying is synonymous with being obedient to something. Meanwhile, obedience is an attitude that appropriately and energetically carries out directions or orders from those who are responsible or powerful towards themselves (Samani and Hariyanto, 2013: 126).

4) Trustworthy 
Trustworthy is defined as something that is entrusted (entrusted) to others. Every mandate always involves two parties, namely the trustee and the trustee.

\subsection{Social Moral Values}

Human relations with other humans in social life often occur friction. Remember man on basically are social beings who need each other, including a relationship with the surrounding environment as a complement in their life sometimes raises various kinds of problems. Human relations with other humans and with the natural surroundings. Representation Social moral values in this study consist of affection, love to give advice, help, and Discussion.

\section{1) Affection}

According to Samani and Hariyanto (2013: 125), affection is a feeling that is manifested in attitudes and behavior that reflect deep and gentle affection for others, so that feelings arise. have one another.

\section{2) Give Advice}

According to Samani and Hariyanto (2013: 116-117), giving advice means showing our wholehearted care or concern for others. Giving advice is also a form of caring and treating others wholeheartedly, kindness, generosity, being sensitive to the feelings of others, ready to help people who need help not to act rude, and hurt others, and care about others.

3) Help each other

According to Samani and Hariyanto (2013: 51), helping out is an attitude or action that is willing to work together with other people to achieve a common goal and mutual benefit.

\section{4) Discussion}

defined as an attitude that shows a sense of pleasure in talking, socializing, and working with others.I 


\subsection{Religious Moral Values}

The human relationship with God is a special relationship. Humans as creatures cannot be separated from the creator. Religious moral values are the mental attitude of humans in dealing with the essence that creates themselves. The representation of religious moral values contained in this study is an attitude of belief in greatness God and pray.

\section{1) Belief in greatness God}

One of God's powers is to create the heavens and the earth and their contents. The contents of the earth include biotic and abiotic, all of which are God's creation. As Almighty and Almighty Creator, God easily creates or destroys what he wants.

2) Supplication

Essentially, someone prays for something that is desired, which is desired or just cool off from everything trouble. Supplication is also one of ways of human communication to God. 


\section{CHAPTER V}

\section{CONCLUSION}

As for the conclusion of the results

This research is:

1. The moral values in the sigale-gale folklore consists of moral value the individual regarding the relationship man with himself, value social morality concerns relationship human with other human inside social environment including thee relationship with the natural environment, and moral values relationship man with God.

2. Character building in the story the people of sigale-gale, consist of a representation of moral values individual in the form of attitude or behavior unyielding, strong, happy, honest, obedient, curious, trustworthy. Representation of social moral values consisting of from a democratic, give advice, love dear, help parents, be alert, respect, mutual help, and friendly. And a representation of value religious moral in the form of trusting attitude God's power and pray. 


\section{REFERENCES}

Sitanggang, S.R.H (2010) SIGALEGALE Cerita Rakyat dari Tapanuli (2010). Jakarta: Pusat Bahasa Kementerian Pendidikan Nasional.

Fitriani, Rafy., Antoni, Rivi., And Rahayu, Pipit. (2016) An Analysis of Moral Values in Novel "Oliver Twist" By Charles Dickens. Jurnal Ilmiah Mahasiswa Prodi Bahasa Inggris. Vol.2 (1).

Warta, Ketut. (2012). Developing Students' Moral Value Through Folklore in Multilingual Setting: A Case Study in The Development of Morality. Journal of Research in Chilhood Education. Vol.32 (3) pp. 295-309.

Kamaruddin SA. (2012). Character Education and Students Social Behavior. Journal of Education and Learning. Vol.6 (4) pp. 223-230.

Karo. Karmila Br. (2018). Moral Value Assessment and Character Education in Folklore in Karo District. Journal Metholange Universitas Methodist Indonesia. Vol.3 (2)

Sayer, I., Kristiawan, M., \& Agustina, M. (2018). Fairy tale as a medium for children's character cooperation building. Al-Ta Lim Journal. Vol.25 (2).

Johardianto. Yohanes., Herawati. Siane., Ningsih. Maria G. Sri. (2018). An Analysis of Moral Value in 47 Ronin Film. Jurnal Ilmiah Bahasa Dan Sastra. Vol.5 (2).

Junaidi. Febi. (2017). The Value of Character Education in Andai-Andai Folklore and Its Use as Learning Material for Literature Subject in Elementary School in Indonesia. Proceedings of Adved 2017. 3.

Pala. Avnur. (2011). The Need for Character Education. International Journal of Social Sciences and Humanity Studies. Vol.3 (2) ISSN. 1309-8063.

Himawan. Romi., Lembah. Gazali., Ulinsa. (2017). Representasi Nilai Moral dalam Cerita Rakyat Kaili di Kabupaten Donggala. Jurnal Electronik Program Pasca Sarjana Tadulako. Vol.5 (4). pp.132-141.

Setyawan. Arief., Suwandi. Sarwiji., Slamet. St. y. (2017). Character Education Values in Pacitan Folklore. Komposisi: Jurnal Pendidikan Bahasa, Sastra, Dan Seni. Vol.18 (1). pp. 90-106.

Suprani. Suprani., Hendracipta. Nana. (2018). The Analysis of Moral Message on Banten's Folklore and Its Learning Process of Character Education- Oriented at Grade Six Sd Negeri Balaraja 2. Jurnal Pendidikan Sekolah Dasar (Jpsd). Vol.4 (1). pp. 102-114. 
English Language Teaching Prima Journal, Vol. 2, No. 1. 2020

e-ISSN: 2686-1526 